\title{
How distance learning based on inclusion led to the proposal of a distributed access research strategy (DARS)
}

\author{
Martin Cabrera \\ Imperial College London, United Kingdom \\ Leidi Yoana Zamudio Garnica, Isabel Cristina Martínez Farfán \\ Corporación Universitaria Iberoamericana, Colombia
}

\begin{abstract}
This article presents the results from an investigation that used a qualitative perspective of a descriptive type to identify the inclusive educational processes from 707 preschool and primary education schools in Colombia, distributed around 26 territorial units out of a total of 32. To obtain all this information around the country, a data collection strategy was applied, which we named the distributed access research strategy (DARS). All the data was collected by tertiary education students from two programs of the Faculty of Education, Corporación Universitaria Iberoamericana in Colombia. The results revealed that most preschools and primary schools have documented institutional educational plans referencing diversity and inclusion for their students, but they have difficulties in establishing strategies to identify and implement curricular adaptations within their contexts, as well as with the use of tracking instruments. These results generated a reflection for reviewing the syllabus and study plans in the tertiary education programs at this university to better prepare future teachers who will face such scenarios in their locations across the country. Moreover, this new DARS datacollection strategy shows an interesting potential, which is generic enough to enable unlimited research topics to be explored within distance learning contexts.
\end{abstract}

Implications for practice or policy:

- University researchers can leverage a data collection strategy based on the distributed students' social network connections.

- Preschools and primary schools should review their management indicators for inclusive practices.

- Universities with education faculties need to reflect on their syllabus and how it supports training future teachers to service diversity scenarios.

- In practice, DARS can be applied to further review how public policies are being applied in a distributed population across the country.

Keywords: distance learning, inclusion, DARS, social network theory, digital equity, inclusive education

\section{Introduction}

Distance learning program offerings, which rely on communications technologies, are becoming more common around the globe (Palvia et al., 2018). This has generated access opportunities for people who were previously outside of the tertiary educational grid (Moloney \& Oakley, 2010). Corporación Universitaria Iberoamericana, located in Colombia, began this journey in 2014, successfully integrating technology tools and tailoring processes to offer online programs. The diversity of students who have enrolled come from across the country, including indigenous communities, disabled populations, students off the electric grid, Afrodescendant communities, people from conflict areas or internally displaced people, populations of rural areas with no nearby universities, and incarcerated students from the penitentiary system. Technology has been a catalyst for change, enabling access for these students who, in turn, will positively transform their communities. It was therefore important to review what could emerge from distance learning, as well as the implications with such heterogeneous and geographically dispersed cohorts.

Research activities are delivered to Corporación Universitaria Iberoamericana students within their programs as part of their graduation prerequisites, and the university has started to develop plans for detecting further opportunities for research. Therefore, the focus is directed towards what can be done and how it can be done, building on an existing set of students. This led to the definition of a new data-collection strategy that was tested with one research initiative to understand its feasibility. The strategy was named DARS, the distributed 
access research strategy. This article presents how the concept was developed and successfully applied to produce research results from an investigation into inclusion processes within a geographically dispersed sample of preschools and primary schools.

\section{Context and digital inclusion}

Inclusion has been a founding concept for Corporación Universitaria Iberoamericana, which is a private university. It started as a special education centre and later became a technical instruction centre. As the institution grew and became a university, it maintained inclusive practices to integrate these populations with other students, becoming the first university in the country to offer a special education degree. For example, during 2017, a total of 27 disabled students graduated, composed of three physically disabled, one partially sighted, and 23 who were hearing impaired. Between 2014 and 2019, over 450 community mothers who take care of vulnerable children or orphans were able to graduate through the university's programs. The inclusion strategy was also able to integrate and graduate 61 victims from the armed conflict in the country during 2017. Overall, $87 \%$ of the student population are women. Therefore, when the opportunity arose to offer distance learning and manage the inclusion of diverse types of students, it was perceived as a natural growth initiative for promote tertiary education through digital inclusion practices (Corporación Universitaria Iberoamericana, 2016).

During 2010, the Colombian government launched an initiative to ensure that all the territories with a population of over 100 people received the required infrastructure to access the Internet and start reducing digital inequality (Ministerio de las Tic, 2010). The deployments were initially applied to government buildings and some public schools. However, the infrastructure could be leveraged to increase the number of connections. Furthermore, the number of existing private and public universities outside of large cities was very small; thus, it did not cover the needs of the population. Such a situation would force students to relocate if they wanted to study, which becomes an economic barrier for them to access tertiary education. This is where the university saw an area of opportunity to start using technology tools to establish a new offer of distance learning.

To achieve that, the university decided to partner with a technology operator that would be able to provide the required technological resources in remote locations and on-site support for students. Since this approach was very different to the on-site methodology that the university was using, a dedicated team from the university administrative staff was formed to build the business and educational operational model. The team had autonomy to custom-build the offering, taking into account the needs from these new student cohorts.

Older marketing methods were used to target prospective students. In many small rural towns, brochures were distributed at schools and at technical education institutions. A megaphone street advertisement was completed to create awareness, alluding to the aspirational motivation for first-generation college students or the first generation within their region. Such an approach had the intention of creating word-of-mouth marketing surrounding the benefits of having professional degrees - both for their own benefit and the benefit of their immediate family and community.

As the new student demographic started to request more information, it transpired that their digital knowledge was very limited. Therefore, introductory on-site computer courses, as well as web tutorials, were introduced as part of the syllabus. Many students had no computers at home, and this was the first time they had been in contact with such technologies. Therefore, in conjunction with the technology operator, small offices called Regional University Tutorial Centres, equipped with computers, were opened in strategic locations. These offices had Internet access and several computers that could be used to teach the students how to use them. Lastly, on Saturdays, the tutorial centres offered live televised classes for all students who could physically attend.

It became evident, with time, that some students depended on these sites for their entire learning experience because they did not have the financial capacity to buy their own computers. As the program expanded, it was humbling to witness the willingness of students to educate themselves. Some travelled from remote indigenous communities, navigating rivers on canoes for several hours to reach these centres. Others travelled from zones off the electric grid and relied on the centres and the technologies there to access the course. Other students had computers, but this was their first experience connecting to the Internet. Education in all basic digital knowledge was therefore required, from learning how to use the tools to adapting to this 
new digitally driven program. These digital inclusion actions were essential to ensure students would be successful. This was marketed as part of the offering in order for them not to exclude themselves from the opportunity, assuming that digital knowledge was a prerequisite.

The distance learning program opened in 2014, initially offering a degree in education before opening degrees in accounting, psychology, and engineering. As more cohorts entered, it became apparent that the demand was not only coming from remote rural areas but also from bigger cities where on-site education offerings were also available. Thus, the offering was also competing with traditional universities that did not have remote education options. Some students were attracted by the flexibility that would enable them to work and study in parallel. As of the end of 2018, several cohorts have graduated, which has brought up the question of how to explore further research opportunities starting from 2019. The university had moved from a centralised teaching scenario within the capital city, to teach to a geographically distributed student population across the country thanks to the new distance learning methodology. Having access to large numbers of students at different locations became an opportunity to conduct research.

\section{Exposure to a geographically dispersed university network and the proposal for DARS}

Based on some of the initial dissertations proposed and successfully implemented by the distance education students, the university became aware that it was gaining access to local knowledge that was previously unavailable from on-site students. For example, one student who was working at a primary school, concerned that her indigenous language would be forgotten over time, decided to start documenting it and including it within the study plans at her location (Rocha, 2017). Another research topic was on discrimination between indigenous, Afrodescendant, and disabled students at a rural school (Banquero, Mejía, \& Zape, 2017). Another dissertation rescued oral traditions regarding children's stories and songs from Afrodescendant culture (Alfaro, Mendoza, \& Yepes, 2018). Such successful student dissertations led to understanding the potential these diverse student populations could bring. Both educational and digital inclusion practices had led the university to gain access to populations that had previously been invisible for research projects. The challenge was how to build on that successful case and how to learn from this student population and their contexts.

For the first phase, we gathered information from all faculties to develop a centralised view of where the university had Regional University Tutorial Centres, as well as to understand where the students were located. This enabled the geographical mapping of the cohorts and how it varied from cohort to cohort, and provided a full view of students under the different faculties. This provided the initial input for considering the opportunities for leveraging the knowledge of such a distributed student population.

For the second phase, we decided to use social network theory to understand social structures based on relationships, where each student can be represented as a node and each relationship with another agent can be understood as their existing ties (Zhang, 2010). In this sense, the intention was to start depicting the relationships between the different university faculties and their students, as well as the geographical location of these students and how influence could be applied to those different groups. As expected, we understood there was cohesiveness across the social network, but particularly through strong, direct ties between the faculties and their respective cohorts spread across the country (Tortoriello, Reagans, \& McEvily, 2011). This was important because the existing faculty-student relationship might enable us to influence both the faculty and its students to undertake tasks for us. Envisioning an ego network, where we are the centre research unit, helped us to understand how the university network expands graphically towards students all over the country (Arnaboldi, Conti, La Gala, Passarella, \& Pezzoni, 2016). This enabled us to understand that our research unit has strong ties with our first-degree connections, who are the university staff from different faculties; and from the faculties' strong ties with their enrolled students, we were able to exert influence over those students, who are second-degree connections for us (Figure 1). 


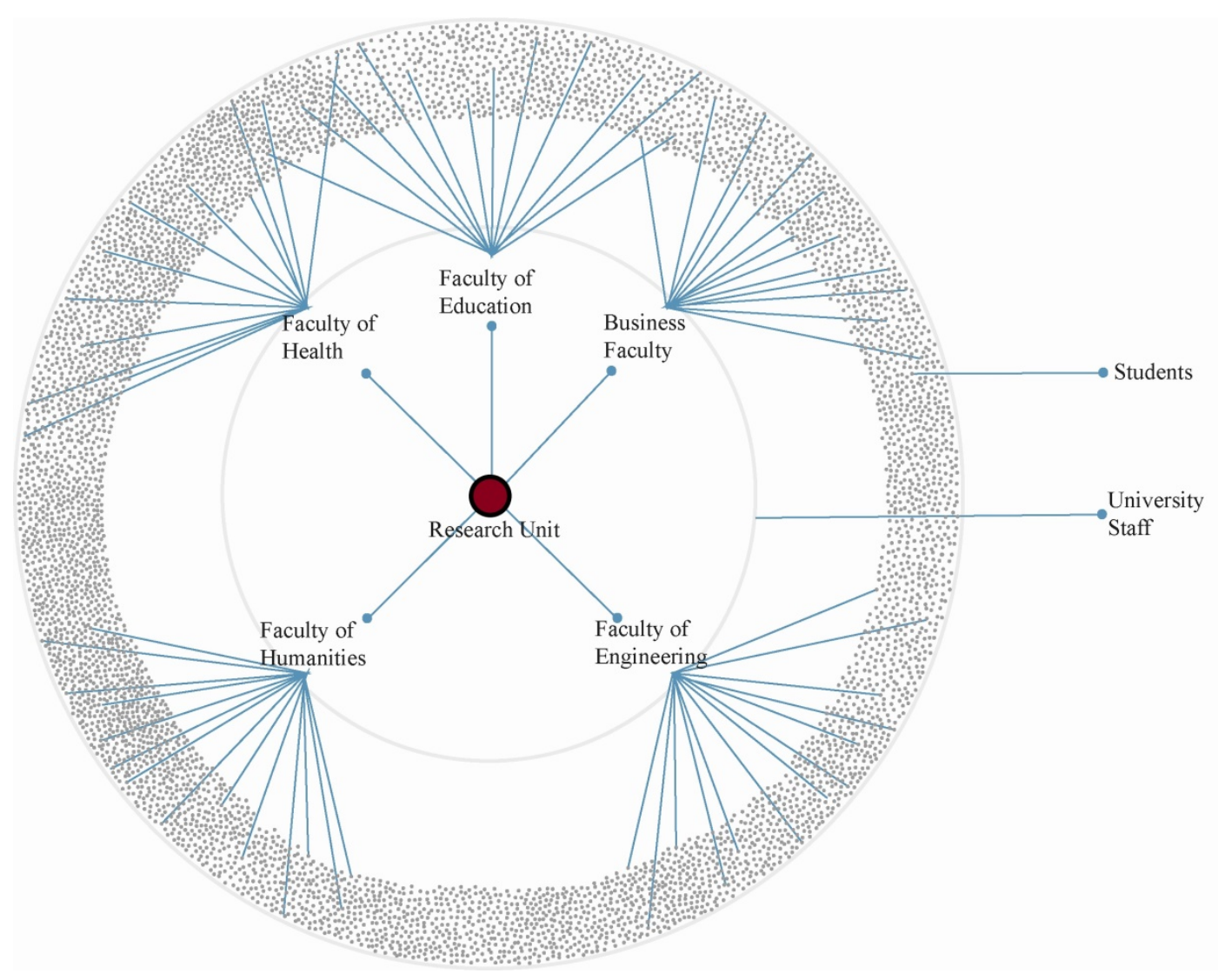

Figure 1. University social network with its approximately 9000 students spread across the country

We also reviewed how students access software applications at the university and proposed a different way of thinking about that access relationship. Student access was, necessarily, granted through what is called an access system in computer science. This is where a user is authenticated in order to gain entry or access to a resource (Lwin, Khaing, \& Tun, 2015). In such systems, users are granted access to the system because of an existing affiliation to it, where certain trust relationships exist. Students are enrolled in the university, and access is therefore granted to university resources, both technological and human. If this was thought of differently and, reversing the analogy, it was acknowledged that this relationship between students and the university could generate common learning, students can potentially also provide access to the university to gain knowledge.

Reversing the concept, with such a trust relationship, students can potentially provide the university with access to academically oriented topics. It is in this sense that Freire (2005) viewed the relationships between students and teachers, where both are simultaneously educators and pupils, learning from one another. From this perspective, the university could leverage its students to both learn and generate knowledge; that could potentially be done not by a computer access system, but by leveraging the students' social connections in their geographical locations.

Students can potentially provide access to a limitless amount of contacts to conduct research for the university. They are already part of the university's social network, and their strong ties with others beyond the university (both persons and institutions) becomes a huge opportunity, if accessed correctly. Traditionally, academic institutions leverage student opinions with surveys. However, the interest here is to leverage their potential relationships without knowing exactly who or what they may be before the research begins. This opens a window to knowledge not previously accessible and exponentially widenes the scope of possibilities for research.

This enhances the initial university social network to include the connections from students geographically dispersed throughout the country. From the ego network depicted, we can navigate through the branches of 
the network to reach students, where all ties are very cohesive, enabling the university to influence students to collaborate with research topics (Friedkin \& Johnsen, 2011). Their strong connections, such as family, friends, and job places (first-degree connections), can provide us access due to the existing trust relationship through the student. There is also the possibility of these connections granting access to their own connections too, thus further expanding the range of possibilities on that second degree of connectivity reach.

Perhaps most important is what Granovetter (1973) understood as weak ties, which are first-degree connections that are not very strong because the interactions are very limited; however, they exist and can be leveraged. Since those weak ties are not very close to the students, those connections probably have access to their own networks of connections (second-degree connections), which are different to the ones that the student has strong ties with. This is important because strong connections usually interact with themselves, and the circles of influence are smaller; however, with the second-degree connections from weak ties, the circle of connections grows enabling more diverse contacts into reach (Granovetter, 1973). This may enable the student to provide us access to even more connections leveraging the second-degree connections from both their strong ties as well as from their weak ties. If this is multiplied by thousands of students, spread around the country, the approach has the potential to access millions of connections in multiple geographies, industries, ethnicities, religions, and institutions.

Let us recall that we are the research unit at the centre and have strong first-degree connections with faculty staff, who can enable us to have strong influence over their enrolled students, who are our second-degree connections. Those students also have first-degree connections and second-degree connections at their geographies. Therefore, our research unit is able to have influence over our third-degree and fourth-degree connections, which is where the scope of research opportunities emerges (Figure 2).

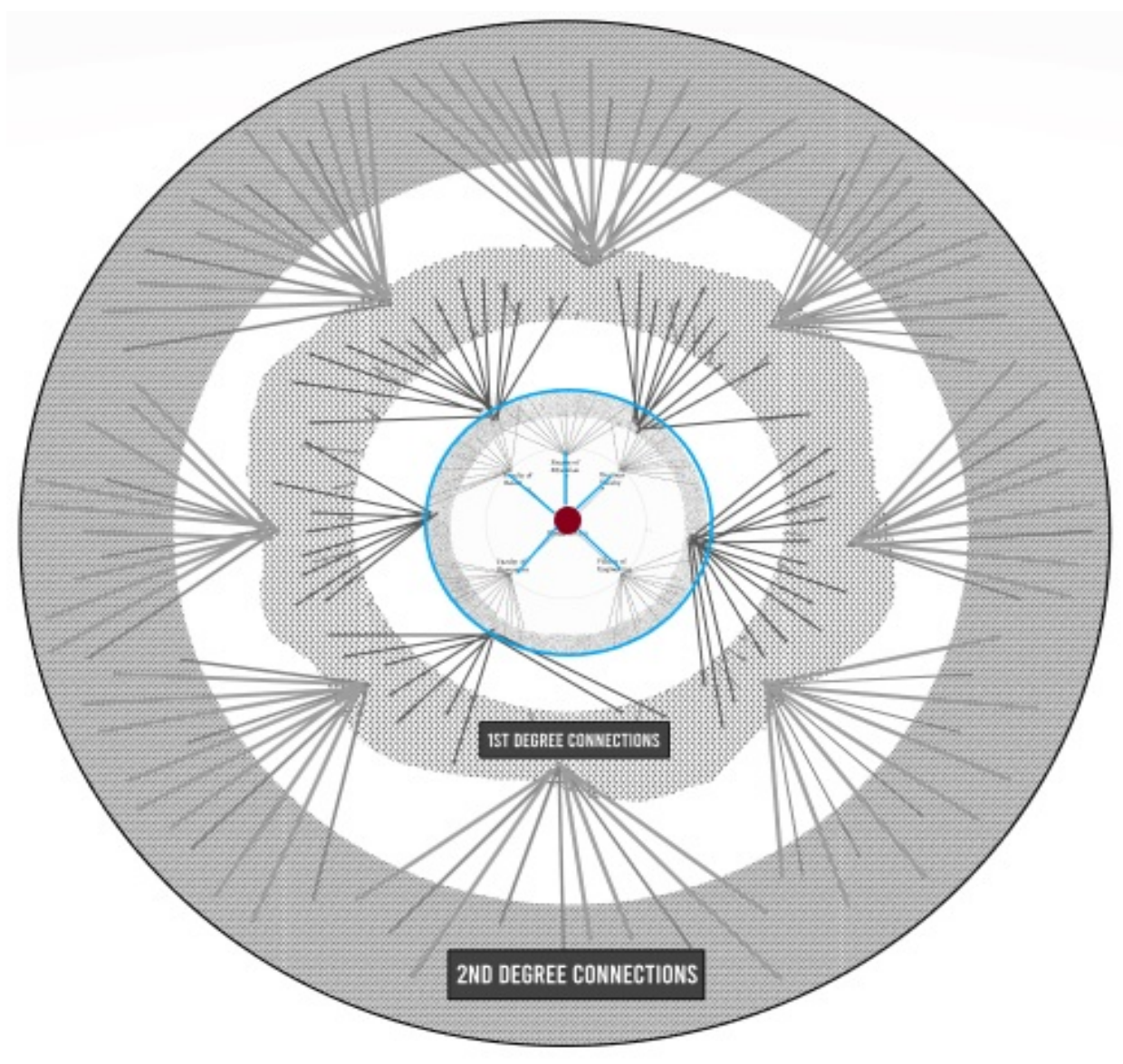

Figure 2. DARS scope of research opportunity leveraging both first- and second-degree connections from the university students 
What is new, from this approach, is to give preference to the potential connections and data that can come from the relationships from these students, rather than the specific data or opinions from the students. The intention is to detect the existence of different relationships that students may have and the huge amount of information that can be accessed through their first- and second-degree connections. Since the university will be interested only in potential connections, there is no need to pre-emptively collect any personal identifiable information from their connections or institutions who they may have a connection with, or to create a database of their specific contacts. That means that, for this strategy, it is not necessary to have the established contacts or know who they are when the investigation is being planned. Therefore, identifying the different categories of connections is more important that the connections themselves. Defining how to categorise the type of existing relationships will enable more targeted investigation options based on the data, as well as how data analysis patterns may help identify data-driven opportunities for research leveraging hundreds of widespread connections in the network (Wayman, 2009).

Since the students are already spread across the country and the university has courses that are related to investigation, the university has the capability to influence and involve students in research tasks while providing them with academic credit or grades in recognition. This is how influence is achieved over the cohesive network of first-degree connections and strong ties that the faculty has with its students. The diverse and geographically distributed student population at hand, as well as the access that students can provide to the university by their social relationships to do research, led us to call this data-collection strategy DARS.

This strategy is better explained with an example: is the acquisition of smartphones at student geographies related to socioeconomic levels? And if they have one, what do they use it for? The university can make a correlational analysis between socio-economic level and smartphone acquisition, leveraging first- and second-degree social network relationships from the students spread across the country, to reach out to 10 of each of their contacts. We do not care who their contacts are before the research begins, as long as we know they exist at their geographical locations. Once the data is collected, only then will we know which connections were leveraged, which is what DARS envisions. Therefore, with just 200 students spread across the country, access would be gained to 2000 connections supplying information. This will be the students' doing - gathering the information in their respective regions and leveraging the university's help in providing the respective investigative instruments to follow. These distributed results can eventually also become inputs for generating positive actions within their communities, such as students teaching others how to use smartphones where gaps are detected, or even considering financial inclusion opportunities leveraging those technologies. The research options are limitless. For this article, we tested DARS with a question about inclusion at preschools and primary schools in Colombia, as will be shown below.

\section{Significance of the study}

The study adds to the reflection on inclusive education as a model for the training of teachers who need to be aware of educational rights. It is relevant for tertiary education institutions in Colombia who train teachers, because it enables us to understand the gaps in inclusion, found in hundreds of preschools and primary schools across the country. It will enable the university to better prepare teachers who will face such scenarios where inclusive practices are not formally established or followed, in order to generate both change and awareness. Students from Corporación Universitaria Iberoamericana had an active role in this research, which also helped the preschools and primary schools participating in the investigation to receive feedback from their educational processes. Furthermore, the study showed the successful application of the datacollection strategy DARS. This replicable data-collection strategy opens unlimited research possibilities for future investigations by the university.

\section{Literature review}

The United Nations Educational, Scientific and Cultural Organization World Conference on Education for All (UNESCO, 1990) highlighted the challenges all countries have in order to meet the learning needs for all within public, private, rural, or urban education. This is very relevant in Colombia when considering the multicultural and multi-ethnic context of the population and its characteristics, which come from a history of armed conflict and post-conflict situations (Rappaport, 2005). Attention to diversity means including everyone; it implies that schools should become places where any human being can be included in all the available educational contexts. Inclusive education requires significant change in the perceptions held by people. Inclusion needs to be understood in different complementary contexts such as in access, permanence, 
promotion, and equity during the educational cycle of the students. Attention to diversity should not be confused only with disability, such as learning disabilities, nor other educational needs; it involves everyone in the learning environment (Posada, Marin, \& Gómez, 2015).

From a legal perspective, the Constitution of Colombia (República de Colombia, 1991), the Law of Education 115 (República de Colombia, 1994), and the National Education Ministry's current decade plan for education 2016-2026 (Ministerio de Educación Nacional, 2016) all reference education and diversity frameworks. Furthermore, Colombia has ratified the eight millennium development goals from the United Nations, which, from 2000 to 2015, have influenced and oriented public policies around inclusion (Noguera \& Ferreira, 2017). The final report from the United Nations Development Programme, informed that, out of Latin America, Colombia was one of the countries that showed the most progress for each of the development goals (United Nations, 2015). However, these results are not homogeneous across the national territories, because the country continues to be listed as part of the most unequal, according to the World Bank GINI index (Statista, 2017). Based on the "Global Education Monitoring Report" (UNESCO, 2016) and the "Global Sustainable Development Report" (United Nations, 2016), the challenge for education in Colombia is urgent. In terms of education, there is still much to be done to achieve equal opportunities, attend to the inclusion of minorities and vulnerable communities, and improve quality in the education being provided. Starting in 2015, Colombia also amended the 2030 Agenda, which has 17 sustainable development goals (United Nations, 2015) - one of which emphasises inclusive and equitable quality education, promoting learning opportunities for all (p. 14).

According to the national guidelines for inclusion policies in tertiary education (Ministerio de Educación Nacional, 2013), inclusion is understood as a central strategy to fight social exclusion. This is also determined by material or objective factors, such as economic or cultural, and by symbolic or subjective factors, such as rejection or indifference (Arizabaleta Domínguez \& Ochoa Cubillos, 2016; Fajardo, 2017; Nosei, 2017). The National Education Ministry understands that efforts towards attention to diversity are necessary (Ministerio de Educación Nacional, 2010). It states that inclusive education can help detect the characteristics and particularities of diverse groups in schools. What enables transformation in educational services is the recognition of the need to provide solutions to diverse situations among students (Correa, Bedoya, \& Agudelo, 2015). This has resulted in proposals that have enabled all to share common spaces - bringing about both participation and coexistence. Such contexts empower an inclusive education that is capable of attending to diversity.

Education is a right that everyone has in order to satisfy basic learning needs; as such, education requires embracing diversity. Achieving that involves the actions of different education participants, as well as the role played by families and communities. If there were responsible entities towards servicing diversity, other than government, that responsibility would fall with the family, school, and the community. There should be an unbreakable active relationship among those three agents in order to achieve inclusive education (Calvo, Verdugo, \& Arnola, 2016; Simón, Giné, \& Echeita, 2016). For inclusive education to exist, significant inclusive educational strategies are required, which are dependent on the context of the student, where all the agents involved are required to commit to inclusion in order to succeed (Marchesi, Blanco, \& Hernández, 2014).

According to Ainscow and Miles (2008), inclusive education can be understood as a reform that sustains and embraces the diversity of all students. Such an approach will always be an ongoing process, as new barriers may arise that can limit both learning and participation. Such barriers can generate exclusion or discrimination in different ways (Booth \& Ainscow, 2002; Booth, Simón, Sandoval, Echeita, \& Muñoz, 2015). Inclusive education therefore depends on contexts and situations that emerge from educational practices. For example, there is inclusion for disability and special needs education. Another situation could be about inclusion as the opposite to disciplinary exclusion, or a scenario of inclusion referred to all excluded vulnerable groups. Yet another understanding of inclusion is the concept of a school for everyone, conceived as education for all, which is developed and implemented as an epistemological framework (Ocampo, 2017).

The index for inclusion (a method for monitoring educational inclusion processes) was written for the Centre for Studies on Inclusive Education (Booth \& Ainscow, 2002. UNESCO (2002) included this index and defined it as a set of materials designed to support schools with their processes and advance towards inclusive education. The index is composed of three questionnaires that collect perceptions from administrative staff, teachers, and students, with respect to 25 indicators that help detect how schools change. There is evidence 
of the inclusion index being applied in schools in Colombia by Echavarría, Rúa, and Pertúz (2012), in the Caribbean region, and Ibero-America (Organización de los Estados Iberoamericanos, 2018). Although there are references to its use in Colombia within the web pages of some of some schools (Gimnasio los Portales, 2019), no results are available.

The curriculum, which is understood as the set of criteria, study plans, methodologies, and processes that contribute to the general training provided to students, also needs to be flexible to embrace diversity and promote inclusion. The curriculum explicitly shows what the institution teaches, through content and resources, and the expected acquired competencies of students, measured by results and evaluations (PratCorominas \& Oriol-Bosch, 2011). The curriculum needs to be oriented and developed for it to provide flexible answers for diverse educational contexts (Posada et al., 2015). Flexibility is of great importance because the opposite would create unintended learning barriers for diverse students, such as high cognitive capacity students or students with disabilities (Sánchez \& Díez, 2012).

\section{Research question and objectives}

The research question that this study sought to answer was: How have inclusive education processes been implemented in the preschool and primary school institutions of the study? To accomplish that, the objectives were, firstly, to identify inclusive education processes and, secondly, to describe inclusive processes. Those objectives would enable us to understand how those schools service diverse populations, starting from their entry up to their graduation. How they are identified in case of requiring special needs, as well as personalised educational processes to guarantee their inclusion, were also of interest.

\section{Methodology}

This article presents the results from an investigation that used a qualitative perspective of a descriptive type in order to identify the inclusive educational processes from 707 preschools and primary education schools in Colombia, distributed around 26 territorial units out of a total of 32 . Based on the research definitions from Hernández, Fernández, and Baptista (2014), qualitative research is understood as a set of interpretative practices that make the world visible, which is transformed into a series of representations documented in observations, annotations, recordings, and documents. This enables researchers to comprehend and deepen their knowledge of phenomena, exploring them from the participants' perspective in a natural setting and in relation to their context. The ethics committee catalogued this proposal as risk-free following Article 11 from resolution 008430/1993 from the Health Ministry of Colombia (Ministerio de Salud, 1993).

Two instruments were elaborated for the study: an observation matrix for each educational institution and an analysis matrix for territorial units.

(1) Firstly, the Registry Matrix of Observations contained basic data such as name, institutional characteristics, geographical region, and specific data on how the student population is serviced. Furthermore, information regarding perceived ethnicities, gender, ages, disabilities (visual, auditive, physical, autistic spectrum), certain cognitive disorders, and special talents detected by the institutions were recorded. The matrix also captured physical or curricular adaptations. There were also questions that required the revision of written processes or documents from the institution that may reference diversity and inclusion. If written evidence was found in the "Institutions Educational Project", which is a document required by law defining what the institution does from a pedagogy perspective, then it was transcribed to the matrix. If the documents mentioned processes related to inclusion, it was requested to describe them and whether the families were involved, as well as other institutions and how those modifications were introduced to better service the student. As the final step, the university student researcher reviewed whether the inclusion index had been used as part of the self-evaluation at the school.

(2) The second instrument was a Consolidation and Analysis Matrix, based on all the results from the Registry Matrix of Observations. The following categories of analysis were included for this instrument:

- Inclusive policies within the school documents

- Implemented processes to attend diversity

- The use of the index of inclusion as a diagnostic and improvement strategy. 


\section{Preparation and logistics}

In order to apply DARS to collect the data from all preschools and primary schools, it was decided that the support provided by the university students would be a graded deliverable from the course they were taking. This was important in order to leverage a strong tie and influence over them. However, imposing tasks upon students was not the intention, nor was it considered the only way to motivate the students to proceed with the research tasks. For example, an initial live virtual meeting was held, recorded, and uploaded to the technology platform that the university uses, leveraging the course web page to present the project, its intentions and goals, and, most importantly, the crucial part that students represented in the process to ensure the success of the investigation.

Considering the students' backgrounds and their context in geographical areas that had been isolated in the past, we highlighted to them that it was important to collect this data, to better understand their geographical areas, which had previously gone unnoticed, for research initiatives. As future teachers, they were told that this would immerse them in a real investigation, which could potentially lead to modifying certain aspects of courses being taught at the university and creating awareness of the problems around inclusion in their own sites. Furthermore, such understanding could help them become managers of change once they became teachers, in order to correct processes and introduce positive change in their communities.

Two subsequent live virtual meetings with students were planned as part of the implementation strategy.

Those meetings were also recorded for students' reference. The second live virtual meeting focused on training students on what they were required to do. This was done in conjunction with the Education Department teachers offering the course, who also provided feedback and peer-reviewed the two proposed research instruments. During these sessions, students were also empowered to reach out to schools they deemed appropriate and accessible for them. This was crucial in order to leverage the DARS approach with students using their connections within their geographical locations. The only instruction was to put in scope any private or public preschools or primary schools near their locations. Before the data collection began, we did not need to know which were their selected schools, as long as we knew schools existed and that they had access to them at their locations through their connections. If their chosen institutions had questions on their request to have access to their processes, students received support from the university, which would provide letters stating that requests by the students were part of a national investigation to gather information.

The training explained how to use the different matrix formats, how to fill them out, and how to document such matters as ethnicities and disabilities. Furthermore, this was reinforced during the live tele-classes provided every Saturday by the university, in order to maintain momentum and information flow during the 2 months that the students took to record the findings. Written instructions were also uploaded to the course's web page, and all matrix formats were to be submitted before a pre-established deadline. If students had specific questions, either the course tutor or ourselves were ready to respond their queries.

A final virtual meeting was held to present the results of the investigation to the students. This helped them see the result of their work and to motivate them to participate in future research. It was also planned that, if research results were published, students would be notified and, if possible, the list of all the students that collaborated would be posted. This was important in order to recognise their efforts and reinforce the culture of generating and sharing knowledge, which the university promotes.

\section{Results and discussion}

It was only during the data consolidation phase that Corporación Universitaria Iberoamericana found out who the participating preschools and primary schools were, which is what the DARS approach envisioned. Research could be initiated without having a previous direct established relationship between the university and, in this case, all those schools. In total, 707 formats from public and private preschools and primary schools were accepted. Of those 707, 93\% were completed by university students from the Children Pedagogy Programme, and $7 \%$ by students from the Special Education Programme. 
Table 1 shows the consolidated data which was extracted from the 26 matrixes of analysis. The table shows the data for each geographical territory in the country, where each territory had its own matrix of analysis before consolidation of all the national data.

Table 1

Consolidation of analysis matrixes

\begin{tabular}{|c|c|c|c|c|c|c|c|c|}
\hline \multirow[t]{2}{*}{ No. } & \multirow[t]{2}{*}{ Territory } & \multirow[t]{2}{*}{$\begin{array}{l}\text { No. of } \\
\text { institutions }\end{array}$} & \multicolumn{2}{|c|}{$\begin{array}{l}\text { Were there } \\
\text { inclusive } \\
\text { policies in the } \\
\text { institutional } \\
\text { documents? }\end{array}$} & \multicolumn{2}{|c|}{$\begin{array}{l}\text { Were there } \\
\text { actions to } \\
\text { respond to } \\
\text { diversity? }\end{array}$} & \multicolumn{2}{|c|}{$\begin{array}{l}\text { Was the index } \\
\text { of inclusion } \\
\text { used as the } \\
\text { diagnostic and } \\
\text { improvement } \\
\text { strategy? }\end{array}$} \\
\hline & & & Yes & No & Yes & No & Yes & No \\
\hline 1 & Antioquia & 67 & 47 & 20 & 40 & 27 & 14 & 53 \\
\hline 2 & Arauca & 25 & 8 & 17 & 4 & 21 & 0 & 25 \\
\hline 3 & Bolívar & 29 & 21 & 8 & 6 & 23 & 8 & 21 \\
\hline 4 & Boyacá & 27 & 15 & 12 & 10 & 17 & 11 & 16 \\
\hline 5 & Caldas & 26 & 17 & 9 & 18 & 8 & 8 & 18 \\
\hline 6 & Caquetá & 26 & 20 & 6 & 14 & 12 & 11 & 15 \\
\hline 7 & Casanare & 15 & 12 & 3 & 8 & 7 & 7 & 8 \\
\hline 8 & Cauca & 58 & 42 & 16 & 22 & 36 & 9 & 49 \\
\hline 9 & Cesar & 31 & 21 & 10 & 10 & 21 & 7 & 24 \\
\hline 10 & Chocó & 9 & 7 & 2 & 8 & 1 & 3 & 6 \\
\hline 11 & Córdoba & 46 & 28 & 18 & 17 & 29 & 11 & 35 \\
\hline 12 & Cundinamarca & 45 & 35 & 10 & 20 & 25 & 2 & 43 \\
\hline 13 & Guajira & 27 & 16 & 11 & 9 & 18 & 0 & 27 \\
\hline 14 & Huila & 1 & 1 & 0 & 1 & 0 & 0 & 1 \\
\hline 15 & Meta & 16 & 11 & 5 & 7 & 9 & 1 & 15 \\
\hline 16 & Nariño & 59 & 52 & 7 & 38 & 21 & 25 & 34 \\
\hline 17 & Norte de Santander & 2 & 1 & 1 & 2 & 0 & 2 & 0 \\
\hline 18 & Putumayo & 53 & 39 & 14 & 38 & 15 & 9 & 44 \\
\hline 19 & Quindío & 3 & 2 & 1 & 1 & 2 & 1 & 2 \\
\hline 20 & Risaralda & 19 & 15 & 4 & 14 & 5 & 3 & 16 \\
\hline 21 & San Andrés & 2 & 0 & 2 & 1 & 1 & 0 & 2 \\
\hline 22 & Santander & 42 & 31 & 11 & 17 & 25 & 6 & 36 \\
\hline 23 & Sucre & 2 & 1 & 1 & 0 & 2 & 0 & 2 \\
\hline 24 & Valle del Cauca & 71 & 63 & 8 & 53 & 18 & 17 & 54 \\
\hline 25 & Vichada & 5 & 4 & 1 & 1 & 4 & 0 & 5 \\
\hline 26 & Yopal & 1 & 1 & 0 & 1 & 0 & 1 & 0 \\
\hline Total & & 707 & 510 & 197 & 360 & 347 & 156 & 551 \\
\hline
\end{tabular}

Figure 1 shows the findings within the institutions regarding the explicit appearance of inclusive policies in their documents. From the data, it was established that $72 \%$ of the schools have policies within their documents referring to the recognition of educational inclusion, while $28 \%$ did not.

Figure 2 shows the perceived actions taken by schools to respond to diversity. From there, 51\% reported having implemented some concrete action, whereas $49 \%$ reported not having executed any action. Some of the documented actions evidenced individual processes implemented to help students. These situations 
included providing classrooms that were prepared to support inclusion and bringing in specialists to diagnose students; in a few cases, the students' parents provided their time to support the student within the classroom. Additionally, some institutions had activities to create awareness around differences to generate tolerance, solidarity, and friendship towards students with functional diversity (cognitive, auditive, or visual).

Figure 3 corroborates the fact that few preschools and primary schools use the inclusion index, representing only $22 \%$ of them. The majority $(78 \%)$ did not use it or did not know it exists. From this analysis and from previous reflections, we concluded that servicing diversity requires that all the involved agents need to be engaged in these processes. That will help guarantee that the students' rights are recognised, starting from the acceptance of differences between persons and the ways diversity can enable an opportunity to enrich educational practices and not be perceived as a problem.

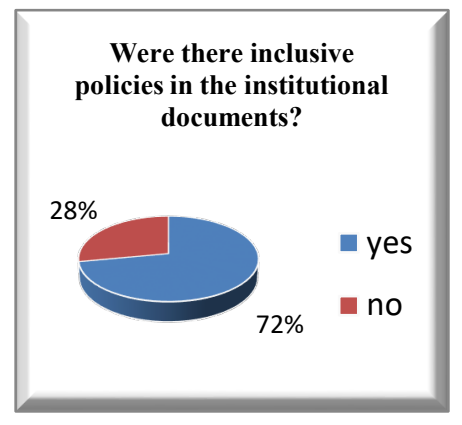

Figure 1. Policies in the institutional documents

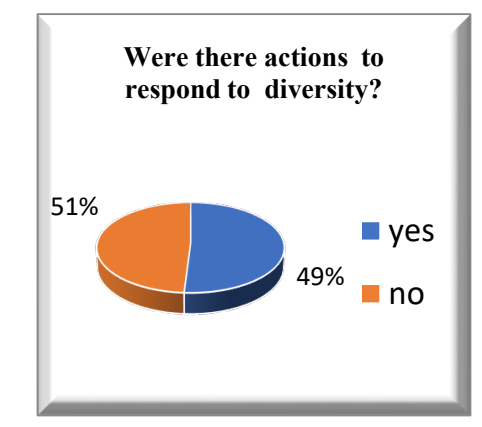

Figure 2. Actions to respond to diversity

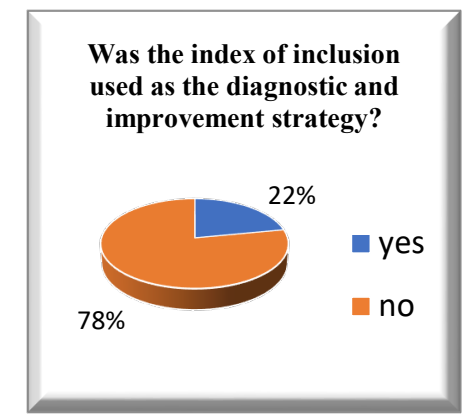

Figure 3. Index for inclusion usage

By contrasting these results with the literature review, the following were established:

(1) The schools in the study are progressing towards recognising inclusive education, not merely associated to disability or with special educational needs (Posada et al., 2015), and understanding it as an opportunity; difference is not a problem, but a learning situation that requires collaborative work. The latter can be achieved by highlighting the importance of access, permanence, promotion, and equity. These are concepts in concordance with the millennium development goals, which also mention inclusive quality education without discrimination (United Nations, 2015). As a member state of the United Nations, Colombia has also embraced both the fourth and tenth sustainable development goals regarding quality education and reduce inequality respectively (United Nations, 2015), as well as the need for inclusive institutions for sustainable development (United Nations, 2016).

(2) The schools claimed to respond to diversity with specific actions. However, family participation was detected only in 2 out of the 707 institutions. An inclusive community involves all of its members, as Calvo et al. (2016) stated; however, families were not included in the institutional inclusion processes. Moreover, teachers have expressed that there is insufficient time assigned to meet with colleagues or families (Marchesi et al., 2014), which brings the challenge of reviewing the number of hours assigned to teachers towards collaborative work tasks as well as with their coresponsibility with others within the community.

(3) The majority of schools did not have tracking processes or auto-evaluations of their inclusion actions. The inclusion index is a tool which can generate reflection on the processes being established for inclusive education. However, it is not being used as mandated by Colombia's National Education Ministry (Ministerio de Educación Nacional, 2010). In the institutions where the inclusion index was applied, the results were consistent with the findings that Echavarría, Rúa, and Pertúz (2012) obtained in applying the inclusion index to the Caribbean region of the country. Their result was of 2.58 over 5.0; however, schools applied the index only once and did not pursue improving their qualification because of the lack of improvement plans and auto-evaluations. What is not continuously evaluated, cannot be improved. 


\section{Limitations}

The size of the sample was not probabilistically representative. Rather, it was a convenience sample which was dependent on the available students from the participating programs. Therefore, some geographical territories had just one or two schools in the sample, which could make it difficult to find significant generalisations or relationships between some territories. The results are significant in the sense that they can be used as part of the reflection on diversity at preschools and primary schools dispersed across the country. This is also important while considering DARS due to the fact that cohort numbers and geographic locations change over time, making the research opportunities dynamic and opportunistic depending on the existing student populations at specific points in time.

Another limitation is the reliability of the data. While collecting the information, students reported that some pedagogic processes were not documented or were incomplete. In some instances, information was collected based on what the schoolteachers remembered due to the lack of formal documents. Lastly, we have no way of contrasting or confirming the collected data.

\section{Implications}

Giving continuity to the path initiated by Molano Caro and Bejarano Gómez (2016), Zamudio and Martínez (2017), Proenza and Acosta (2017), Arias and Blanco (2018), and Arias and Ayala (2018), it will be necessary to consolidate management indicators on inclusive education. It is also imperative to reflect on how the study plans from Corporación Universitaria Iberoamericana, and its syllabus, are responding to training teachers capable of understanding and bringing change with respect to inclusion within their schools. Furthermore, the feasibility of DARS to collect data was proven with the success of the aforementioned formal investigation. Students benefitted from the experience of being part of a distributed research team, applying research methodologies, and learning how preschools and primary schools in their context were dealing with inclusion. DARS also proved successful due to the high level of engagement from students. Even though it was part of their coursework, with a grade assigned to it, most of the deliverables achieved the expected quality levels. From all the formats that were consolidated, $94 \%$ were classified as feasible for use. The remaining $6 \%$ were from students who either did not deliver the formats or were unable to comply with the expected quality levels. This is important to have as a reference value in future research and to determine whether that percentage is consistent to better predict sample data in the future.

For the university, leveraging the students' social networks enables access to geographies and connections that were unimaginable in the past. This also foments the duality in the learning experience, where students learn from the university and its educational and research proposals and the university learns from the access provided by the students' connections within their contexts. Such interactions can also make it easier for content and knowledge to be more contextualised in the reality of the students.

The successful application of DARS demonstrated that this approach is replicable, enabling infinite amounts of research possibilities within the university, which could also be used by other institutions. The power of the student social networks opened opportunities for gaining knowledge from distributed sources providing us access to third-degree and fourth-degree connections in the network. In this case, the distribution was across a single country. As universities start departing from the limitations of physical space due to the technological disruption in education, which is leading towards changes in the educational paradigm, some have been able to build a global presence of students (Cabrera, 2018). That can also be leveraged for research spanning over continents. Alternatively, different university networks of students can work towards joint research that would exponentially increase the scope of opportunity.

As for next steps, the plan is to engage further research proposals using this data-collection strategy. In this initial stage, the social network connections that were leveraged from the students were based on common social institutions that are available in most social community contexts. These include healthcare institutions, government institutions, schools, churches, people, and businesses, which are inevitably part of any student or modern society social network (Gelles \& Levine, 2000). However, if student data is collected from the moment they join the university, there is a potential to gain better granularity on the range of opportunities. Furthermore, cohorts and the geographic locations of students change over time; thus, the possible social network relationships also change, which means that research opportunities will also change over time depending on the students who are enrolled at a specific point in time. The DARS approach has shown that 
the interest relies on the relationships that the student social network may provide. Therefore, personal identifiable information from the students and their contacts is not necessary. That generates the possibility of collecting data from students based on criteria or a categorisation defined by each of the university's faculties, where patterns within the data may emerge with the potential to become research projects. This becomes a digitally driven strategy based on data where research options emerge from such data analysis.

\section{Conclusion}

Most preschools and primary schools in the study have documents about inclusion processes that emphasise the access and permanence of students within the school. However, with over half of the schools, flexibility within their curriculums or physical adaptations when faced with inclusion scenarios were not present in their general activities. The data we collected evidences the priority given by preschools and primary schools from this study to maintain the identity, language, and customs of territorial units with the presence of indigenous populations. Most institutions agreed to being respectful of both visible and non-visible differences between students, as well as to their traditions, culture, and languages. There was little evidence of adaptations being made due to the lack of knowledge about inclusion processes. Difficulty characterising or providing proper diagnosis of development disorders and disabilities was detected. In some schools, students were accepted, but years went by where some graduated or others dropped out without being diagnosed by multidisciplinary teams, which is a starting point for inclusive education processes.

Diversity is a challenge for preschools and primary schools. However, the first step in generating change is to perceive inclusive education as a determining factor in the construction of a more equal society that can close the gap of inequality. That leads to discussions of diversity and identity in parallel, in order to recognise everyone within their differences. That is why Corporación Universitaria Iberoamericana will continue to provide the necessary tools to the future teachers being trained, to enable them to understand and act accordingly with respect to diversity. The idea of equality is quite recent in human history, gaining attention in the 1940s with the Universal Declaration of Human Rights by the United Nations (United Nations, 1948). Since this is somewhat new for all countries, the challenge is to be able to generate an inclusive education that can be provided with quality. Furthermore, Colombia is going through a post-conflict phase, which makes it necessary to implement schools that are more inclusive. These institutions will enable citizens to coexist and provide equal opportunities to access, remain, and graduate from them.

\section{Acknowledgements}

The authors would like to thank all 707 university students who participated in this research initiative and the GIEEP (Grupo de Investigación en Educación y Escenarios de Construcción Pedagógica) Research Group of the Education Faculty of Corporación Universitaria Iberoamericana.

\section{References}

Ainscow, M., \& Miles, S. (2008). Por una educación para todos que sea inclusiva: ¿Hacia dónde vamos ahora? [Making education for all inclusive: Where next?]. Perspectivas, 38(1), 17-44. Retrieved from http://www.ibe.unesco.org/fileadmin/user_upload/Publications/Prospects/Prospects145_spa.pdf page $=20$

Alfaro, D., Mendoza, A., \& Yepes, Y. (2018). Los cuentos y las rondas tradicionales como estrategias para el fortalecimiento de la competencia del lenguaje en los factores de comprensión textual y literatura, de los niños de 7 a 12 años de la IE Benjamín Herrera, Arjona-Bolívar [Traditional stories and songs as a strategy to strengthen language competencies for reading comprehension with children from 7 to 12 years old at IE Benjamín Herrera, Arjona-Bolívar] (Undergraduate dissertation). Retrieved from http://repositorio.iberoamericana.edu.co/handle/001/832

Arias Castilla, C. A., \& Ayala Cardona, J. A. (2018). Diversidad en Educación Infantil: programas de formadores para la infancia en Colombia [Diversity in preschool education: Programs of teachers for infants in Colombia]. Bogota, Colombia: Corporación Universitaria Iberoamericana. Retrieved from http://repositorio.iberoamericana.edu.co/handle/001/595

Arias Castilla, C., \& Blanco Vega, M. de J. (2018). Evaluación para el mejoramiento de la formación docente en educación infantil: reto de la profesionalización del servicio educativo [Evaluation to 
improve teacher training for preschool education: The challenge to proffesionalise education services]. Revista Iberoamericana De Educación, 77(1), 153-174. https://doi.org/10.35362/rie7713123

Arizabaleta Domínguez, S. L., \& Ochoa Cubillos, A. F. (2016). Hacia una educación superior inclusiva en Colombia [Towards an inclusive higher education in Colombia]. Pedagogía y Saberes, 45, 41-52. Retrieved from http://www.scielo.org.co/pdf/pys/n45/n45a05.pdf

Arnaboldi, V., Conti, M., La Gala, M., Passarella, A., \& Pezzoni, F. (2016). Ego network structure in online social networks and its impact on information diffusion. Computer Communications, 76, $26-41$. https://doi.org/10.1016/j.comcom.2015.09.028

Banquero, D., Mejía, L., \& Zape, N. (2017). Huellas de paz, fortalecimiento de la convivencia escolar a través del reconocimiento de la diversidad en la institución educativa el Palmar sede la Toma del municipio de Santander de Quilichao [Footprints of peace, strengthening school coexistence by recognizing diversity in the School Palmar from Toma in Santander de Quilichao] (Unpublished undergraduate dissertation). Corporación Universitaria Iberoamericana, Bogota, Colombia.

Booth, T., \& Ainscow, M. (2002). Index for inclusion: Developing learning and participation in schools. Bristol, United Kingdom: Centre for Studies on Inclusive Education. Retrieved from http://www.csie.org.uk/resources/translations/IndexEnglish.pdf

Booth, T., Simón, C., Sandoval, M., Echeita, G., \& Muñoz, Y. (2015). Guía para la Educación Inclusiva. Promoviendo el aprendizaje y la participación en las escuelas: Nueva edición revisada y ampliada [Guide for inclusive education: Promoting learning and participation at schools: new revised and extended edition]. Revista Iberoamericana sobre Calidad, Eficacia y Cambio en Educación, 13(3), 519. Retrieved from http://www.rinace.net/reice/numeros/arts/vol13num3/art1.pdf

Cabrera, M. (2018). Filosofía de la tecnología: de la "techné" clásica al actuar de la tecnología disruptiva [Philosophy of technology: From classical "techné" to the behavior of disruptive technology] (Master's dissertation). Retrieved from http://hdl.handle.net/10554/35920

Calvo, M.,Verdugo, M., \& Arnola, A. (2016). Participación Familiar es un Requisito Imprescindible para una Escuela Inclusiva [Family participation is an essential requisite for an inclusive school]. Revista Latinoamericana de Educación Inclusiva, 10(1), 99-113. https://doi.org/10.4067/S071873782016000100006

Corporación Universitaria Iberoamericana. (2016). Proyecto de Inclusión y Educación Iberoamericana PIEI [Project for inclusion and education iberoamericana PIEI]. Bogota, Colombia: Author. Retrieved from http://www.ibero.edu.co/wp-content/uploads/2018/05/PIEI IBERO1-1.pdf

Correa, J., Bedoya, M., \& Agudelo, G. (2015). Formación de docentes participantes en el programa de educación inclusiva con calidad en Colombia [Training teachers participating in the quality inclusive education program in Colombia]. Revista Latinoamericana de Educación Inclusiva, 9(1), 43-61. Retrieved from http://www.rinace.net/rlei/numeros/vol9-num1/art2.pdf

Echavarría, J., Rúa, M., \& Pertúz, E. (2012). Una estrategia para la educación inclusiva [A strategy for inclusive education]. Escenarios, 10(2), 30-37. https://doi.org/10.15665/esc.v10i2.216

Fajardo, S. (2017). La Educación Superior Inclusiva en Algunos Países de Latinoamérica: Avances, Obstáculos y Retos [Inclusive higher education in some Latin American countries: Progress, obstacles and challenges]. Revista Latinoamericana de Educación Inclusiva, 11(1), 171-197. Retrieved from http://www.rinace.net/rlei/numeros/vol11-num1/art9.html

Freire, P. (2005). Pedagogy of the oppressed (30th anniversary ed.). (M. Bergman Ramos, Trans.). New York, NY: Continuum. (Original work published 1970, 1993) Retrieved from https://www.academia.edu/37919934/Pedagogy_of_the_oppressed_by_Paulo_Freire

Friedkin, N., \& Johnsen, E. (2011). Social influence network theory: A sociological examination of small group dynamics. Cambridge, MA: Cambridge University Press. https://doi.org/10.1017/CBO9780511976735

Gelles, R., \& Levine, A. (2000). Sociología con aplicaciones en países de habla hispana (Sexta Edición). [Sociology with application to Spanish speaking countries (6th ed.)]. Bogota, Colombia: McGraw-Hill.

Gimnasio Los Portales. (2019). GP Política de Inclusión [GP Inclusion policy]. Retrieved from https://www.losportales.edu.co/wp-content/uploads/2019/03/GP Política de Inclusión.pdf

Granovetter, M. S. (1973). The strength of weak ties. American Journal of Sociology, 78(6), 1360-1380. https://doi.org/10.1086/225469

Hernández, R., Fernández C., \& Baptista, P. (2014). Metodología de la investigación (Sexta Edición) [Research methodology (6th ed.)]. Mexico City, Mexico: McGraw-Hill. Retrieved from http://observatorio.epacartagena.gov.co/wp-content/uploads/2017/08/metodologia-de-la-investigacionsexta-edicion.compressed.pdf 
Lwin, H., Khaing, A. \& Tun, (2015). Automatic door access system using face recognition. International Journal of Scientific \& Technology Research, 4(6), 294-299. Retrieved from http://www.ijstr.org/finalprint/june2015/Automatic-Door-Access-System-Using-Face-Recognition.pdf

Marchesi, A., Blanco, R., \& Hernández, L. (2014). Avances y desafios de la educación inclusiva en Iberoamérica [Progress and challenges for inclusive education in Ibero-America]. Madrid, Spain: Organización de Estados Iberoamericanos para la Educación, Ciencia y la Cultura. Retrieved from https://www.oei.es/historico/publicaciones/Metas inclusiva.pdf

Ministerio de Educación Nacional. (2010). Educación inclusiva con calidad "Construyendo capacidad institucional para la atención a la diversidad" [Quality inclusive education "building institutional capabilities towards servicing diversity]. Guía 11. Bogota, Colombia: Author. Retrieved from https://www.mecd.gob.es/dms-static/31ca0e0d-763a-433a-b92e-0d1829d5afd2/2010-bp-11-colombiaff2-pdf.pdf

Ministerio de Educación Nacional. (2013). Lineamientos de Política de Educación Superior Inclusiva [Guidelines for tertiary education inclusion policies]. Bogota, Colombia: Author. Retrieved from https://www.mineducacion.gov.co/1759/w3-article-357277.html

Ministerio de Educación Nacional. (2016). Plan Decenal de Educación 2016-2026 [Decade plan for education]. Bogota, Colombia: Author. Retrieved from http://eduteka.icesi.edu.co/articulos/men-pnde2017

Ministerio de las Tic. (2019). Estadísticas para consulta [Statistics for consultancy]. Retrieved from https://colombiatic.mintic.gov.co/679/w3-channel.html

Ministerio de Salud (1993). Resolución número 8430 de 1993 [Resolution number 8430 from 1993]. Bogota, Colombia: Author. Retrieved from

https://www.minsalud.gov.co/sites/rid/Lists/BibliotecaDigital/RIDE/DE/DIJ/RESOLUCION-8430DE-1993.PDF

Molano Caro, G., \& Bejarano Gómez, J. A. (2016). La inclusión desde la institución educativa. In Y. Rodríguez Hernández, G. E. Rodríguez Jiménez, C. A. Arias Castilla, G. Molano Caro, J. A. Bejarano Gómez, S. M. Camargo Mendoza, \& J. A. Méndez Medina (Eds.), Diversidad e Inclusión: Reconocer lo que Hacemos [Diversity and inclusion: Recognising what we do] (pp. 126-185). Bogota, Colombia: Corporación Universitaria Iberoamericana. Retrieved from http://repositorio.iberoamericana.edu.co/handle/001/487

Moloney, J., \& Oakley, B.. (2010). Scaling online education: Increasing access to higher education. Journal of Asynchronous Learning Networks. Retrieved from ERIC database. (EJ909842)

Noguera, F., \& Ferreira, J. (2017). Peace and sustainable development in Colombia. Bogota, Colombia: Asociación de Fundaciones Empresariales, AFE Sustainable Development Goals Philanthropy Platform. Retrieved from https://www.sdgphilanthropy.org/system/files/201711/Peace $\% 20$ and $\% 20$ Sustainable $\% 20$ Development $\% 20 \mathrm{in} \% 20$ Colombia.pdf

Nosei, C. (2017). Pedagogías de las diferencias [Pedagogy of differences]. Praxis Educativa, 21(1), 6567. https://doi.org/10.19137/praxiseducativa-2017-210107

Ocampo, A. (2017). Epistemología de la Educación Inclusiva: Un estudio sobre sus condiciones de producción y fabricación del conocimiento [Epistemology of inclusive education: A study about its conditions of knowledge production and fabrication] (Doctoral dissertation). Retrieved from https://dialnet.unirioja.es/servlet/tesis?codigo $=128454$

Organización de los Estados Iberoamericanos. (2018). OEI y UNESCO presentan una guía de inclusion y equidad educative para Iberoamérica [OEI and UNESCO present an inclusion and equity education guide for Ibero-America]. Retrieved from https://www.oei.es/en/Education/News/oei-y-unescopresentan-una-guia-de-inclusion-y-equidad

Palvia, S., Aeron, P., Gupta, P., Mahapatra, D., Parida, R., Bosner, R., \& Sinhi, S. (2018) Online education: Worldwide status, challenges, trends, and implications. Journal of Global Information Technology Management, 21(4), 233-241. https://doi.org/10.1080/1097198X.2018.1542262

Posada, Y., Marín, Y. \& Gómez, S. (2015). La diversidad funcional y las adaptaciones curriculares [Functional diversity and curricular adaptations]. Revista de Investigaciones UCM, 15(26), 192-202. Retrieved from http://www.revistas.ucm.edu.co/ojs/index.php/revista/article/view/55

Prat-Corominas, J., \& Oriol-Bosch, A. (2011). Proceso de Bolonia (IV): currículo o plan de estudios. [Bologna Process (IV): Curriculum or study plan]. Editorial Educación Médica, 14(3), 141-149. Retrieved from https://www.um.es/c/document library/get file?uuid=545611e3-606a-4026-bb7488965ba0f2b0\&groupId=115466

Proenza Pupo, J., \& Acosta Guerra, G. (2017). La educación inclusiva para estudiantes sordos en la Corporación Universitaria Iberoamericana de Colombia [Inclusive education for deaf students at 
Corporación Universitaria Iberoamericana in Colombia]. LUZ, 16(1), 1-9. Retrieved from https://luz.uho.edu.cu/index.php/luz/article/view/791

Rappaport, J. (2005). Intercultural utopias: Public intellectuals, cultural experimentation, and ethnic pluralism in Colombia. Durham, United Kingdom: Duke University Press.

República de Colombia. (1991). Constitución Política de Colombia [Political Constitution of Colombia]. Bogota, Colombia: Secretaría del Senado. Retrieved from http://wsp.presidencia.gov.co/Normativa/Documents/Constitucion-Politica-Colombia.pdf

República de Colombia. (1994). Ley 115, Ley general de educación [Law 115, General Law of Education]. Bogota, Colombia: Congreso de la Republica de Colombia. Retrieved from https://www.mineducacion.gov.co/1621/articles-85906_archivo_pdf.pdf

Rocha, N. (2017). Transversalización de la lengua nasa yuwe [Mainstreaming of the nasa yuwe language]. (Unpublished undergraduate dissertation). Corporación Universitaria Iberoamericana, Bogota, Colombia.

Sánchez, S., \& Díez, E. (2012). La educación inclusiva desde el currículum: el diseño universal para el aprendizaje. In H. Rodríguez Navarro \& L. Torrego Egido (Eds.), Educación inclusiva, equidad y derecho a la diferencia [Inclusive education, equity and rights to differences] (pp. 107-119). Alphen aan den Rijn, The Netherlands: Wolters Kluwer. Retrieved from https://www.researchgate.net/publication/261833343

Simón, C., Giné, C. \& Echeita, G. (2016). Escuela, familia y comunidad: Construyendo alianzas para promover la inclusión [School, family and community: Building alliances to promote inclusion]. Revista Latinoamericana de Educación Inclusiva, 10(1), 25-42. Retrieved from https://scielo.conicyt.cl/scielo.php?script $=$ sci_abstract\&pid $=$ S0718$73782016000100003 \& \operatorname{lng}=\mathrm{es} \& \mathrm{nrm}=\mathrm{iso}$

Statista. (2017). Income distribution inequality based on Gini coefficient in Latin America as of 2017, by country. Retrieved from https://www.statista.com/statistics/980285/income-distribution-ginicoefficient-latin-america-caribbean-country/

Tortoriello, M., Reagans, R., \& McEvily, B. (2011) Bridging the knowledge gap: The influence of strong ties, network cohesion, and network range on the transfer of knowledge between organizational units. Organization Science, 23(4). https://doi.org/10.1287/orsc.1110.0688

United Nations. (1948). Universal Declaration of Human Rights. Retrieved from https://www.un.org/en/universal-declaration-human-rights/

United Nations. (2015). Resolution adopted by the General Assembly on 25 September 2015. Transforming our world: The 2030 Agenda for sustainable development. Retrieved from https://www.un.org/en/development/desa/population/migration/generalassembly/docs/globalcompact/A RES 70_1_E.pdf

United Nations. (2016). Global sustainable development report. Retrieved from https://sustainabledevelopment.un.org/globalsdreport/2016

United Nations Educational, Scientific and Cultural Organization. (1990). World Declaration on Education for All and the Framework for actions to meet learning basics needs. Paris, France: Author. Retrieved from https://unesdoc.unesco.org/ark:/48223/pf0000127583

United Nations Educational, Scientific and Cultural Organization. (2002). Education for All: Is the world on track? (EFA Global Monitoring Report 2002). Paris, France: Author. Retrieved from https://unesdoc.unesco.org/ark:/48223/pf0000129053

United Nations Educational, Scientific and Cultural Organization. (2015). La Educación para Todos, 2000-2015: logros y desafios, informe de seguimiento de la EPT en el mundo, 2015 [Education for all 2000-2015: Goals and challenges, report and tracking of EFA in the world, 2015]. Paris, France: Author. Retrieved from https://unesdoc.unesco.org/ark:/48223/pf0000232565 spa

United Nations Educational, Scientific and Cultural Organization. (2016). Education for people and planet: Creating sustainable futures for all (Global Education Monitoring Report 2016). Paris, France: Author. Retrieved from http://unesdoc.unesco.org/images/0024/002457/245752e.pdf

Wayman, J. (2009) Involving teachers in data-driven decision making: Using computer data systems to support teacher inquiry and reflection. Journal of Education for Students Placed at Risk, 10(3), 296308. https://doi.org/10.1207/s15327671 espr1003_5

Zamudio, L. \& Martínez, I. (2017). Hacia el Fortalecimiento de la Atención a la Diversidad en Colombia: la educación inclusiva desde la formación de docentes [Towards the strengthening of attention to diversity in Colombia: Inclusive education for teachers' training]. Paideia, 60, 41-63. Retrieved from http://www.revistapaideia.cl/index.php/PAIDEIA/article/view/154/122 
Zhang, M. (2010). Social network analysis: History, concepts, and research. In B. Furht (Ed.), Handbook of social network technologies and applications (pp. 3-21). Boston, MA: Springer. https://doi.org/10.1007/978-1-4419-7142-5 1

Corresponding author: Martin Cabrera, martin.cabrera@citi.com

Copyright: Articles published in the Australasian Journal of Educational Technology (AJET) are available under Creative Commons Attribution Non-Commercial No Derivatives Licence (CC BY-NC-ND 4.0). Authors retain copyright in their work and grant AJET right of first publication under CC BY-NC-ND 4.0 .

Please cite as: Cabrera, M., Zamudio, L., Martinez, I. (2019). How distance learning based on inclusion led to the proposal of a distributed access research strategy (DARS). Australasian Journal of Educational Technology, 35(6), 80-96. https://doi.org/10.14742/ajet.5525 